\title{
Crops Responses to Mite Infestation: It's Time to Look at Plant Tolerance to Meet the Farmers' Needs
}

\author{
Raul A. Sperotto ${ }^{1,2 *}$, Giseli Buffon ${ }^{1}$, Joséli Schwambach ${ }^{3}$ and Felipe K. Ricachenevsky ${ }^{4,5}$ \\ ${ }^{1}$ Graduate Program in Biotechnology, University of Taquari Valley, Lajeado, Brazil, ${ }^{2}$ Biological Sciences and Health Center, \\ University of Taquari Valley, Lajeado, Brazil, ${ }^{3}$ Graduate Program in Biotechnology, University of Caxias do Sul, Caxias do Sul, \\ Brazil, ${ }^{4}$ Graduate Program in Agrobiology, Federal University of Santa Maria, Santa Maria, Brazil, ${ }^{5}$ Graduate Program in Cell \\ and Molecular Biology, Federal University of Rio Grande do Sul, Porto Alegre, Brazil
}

Keywords: antibiosis, antixenosis, plant defense, tolerance, herbivore performance

OPEN ACCESS

Edited by:

Brigitte Mauch-Mani,

University of Neuchâtel, Switzerland

Reviewed by:

Marcos Antonio Matiello Fadini, Universidade Federal de São João del-Rei, Brazil

*Correspondence:

Raul A. Sperotto rasperotto@univates.br

Specialty section:

This article was submitted to Plant Microbe Interactions,

a section of the journal

Frontiers in Plant Science

Received: 24 February 2018

Accepted: 09 April 2018

Published: 24 April 2018

Citation:

Sperotto RA, Buffon $G$

Schwambach $J$ and

Ricachenevsky FK (2018) Crops Responses to Mite Infestation: It's Time to Look at Plant Tolerance to Meet the Farmers' Needs.

Front. Plant Sci. 9:556.

doi: 10.3389/fpls.2018.00556
It is common to see crop farmers struggling to solve herbivore infestations. Normally, worry starts when herbivore population increases and leaf damage is apparent. Whatever the treatment chosen by the farmer (chemical or biological) to control it, yield and productivity are the final and most important characteristics they would like to see unaffected by herbivory. Certainly, farmers would be less interested in percentage of leaf damage or mite population increase, which are useful but limited approximations of tolerance, than maintenance of crop production even under infested conditions. If a crop can stand infestation and/or larger mite populations while still producing the same seed set, the crop is, from a farmer standpoint, tolerant. On the other hand, academic studies on the field of plant-herbivore interaction are still based on resistance mechanisms in vegetative tissues and herbivore performance, rather than the plant reproductive success. We should be aware that genetic breeding for tolerance should focus on comparing seed production when dealing with most crops, not indirect measures such as leaf damage or mite population dynamics.

\section{RESISTANCE/TOLERANCE MECHANISMS}

The interactions between herbivores and plant hosts result from an elaborate evolutionary interplay: plants have developed strategies to arrest attackers and reduce pest fitness as a defense against herbivory, while herbivores have evolved mechanisms to overcome that (Rioja et al., 2017). Such defense strategies include several modifications that reduce the negative impact of herbivores on a plant's reproductive success (i.e., the production of fertile offspring) and increase the plant's fitness (i.e., its contribution to the gene pool of the next generation) as a function of herbivory (Erb, 2018). Plants that efficiently and effectively use these defense strategies are called "pest-resistant" (which can be broadly classified into two different mechanisms, antibiosis and antixenosis - Stenberg and Muola, 2017), or "pest-tolerant" (Mitchell et al., 2016). Antibiosis mechanisms affect pest biology in a deleterious manner (Peterson et al., 2017), decreasing herbivore fitness or performance (e.g., fertility rate or larval development time - Stenberg and Muola, 2017). Antixenosis mechanisms direct a pest away from the plant (Peterson et al., 2017), decreasing the herbivore presence (number of eggs, larvae, or adults) and, consequently, the herbivore damage (e.g., percentage of leaf area removed - Stenberg and Muola, 2017). On the contrary, tolerance mechanisms allow the plants to withstand pest injury and produce acceptable yields, maintaining the fitness under stressful conditions, without affecting pest biology or behavior, which creates 
little selective pressure on pest populations and therefore does not generate resistant variants to the tolerant plants (Peterson et al., 2017).

\section{TOLERANCE: MUCH LESS STUDIED THAN ANTIBIOSIS OR ANTIXENOSIS}

Recently, a tricky and artful question was made by Peterson et al. (2017): is tolerance the forgotten child of plant resistance? This questioning came from the fact that it has received the least attention of the three types of plant defenses (or the three types of plant resistance, according to some authors that consider tolerance as the third type of plant resistance). According to Erb (2018), most plant defenses are still characterized by proximate variables such as herbivore performance or plant damage rather than actual fitness, which means that antibiosis and antixenosis (resistance subtypes) are more commonly used than tolerance to describe plant behavior against herbivorous pests. This is evidenced by the data presented in Table 1. Since 2009, we found 25 articles describing phytophagous mite interaction with crop species, and only four analyzed plant yield under infested condition (Karmakar, 2009; Vichitbandha and Chandrapatya, 2011; Nyoike and Liburd, 2013; Warabieda, 2015). The most common group of measures to assess defenses are herbivore performance traits, including mite population, survival, development and oviposition rates, along with leaf damage (Table 1). Peterson et al., 2017) list five reasons why tolerance has not been developed as successfully as antibiosis and antixenosis: (1) tolerance is difficult to identify, and the mechanisms conferring it are poorly understood; (2) the genetics of tolerance is mostly unknown; (3) high-throughput phenotyping methods for large-scale screening of tolerance are still missing; (4) most of the entomologists are interested in mechanisms which affect pest biology, not plant biology (highlighting the need for interdisciplinary research between plant scientists and entomologists); and (5) plant resistance efforts are still directed at controlling pest populations rather than managing plant stress.

\section{WHY RESISTANCE ANALYSIS CAN BE PROBLEMATIC?}

Even though the importance of data on plant reproductive success and yield in plant defense studies has been previously emphasized (Clavijo McCormick et al., 2012; Poelman, 2015), the plant-herbivore community still have difficulties to use the appropriate fitness analysis in combination with recent methodological advances to increase our understanding of plant defense traits (Erb, 2018). Therefore, herbivore performance traits and leaf damage-proximate variables, according to Erb (2018) - still are the first options. However, proximate variables has several strong limitations. For example, herbivore population can be a poor predictor of feeding damage ( $\mathrm{Lu}$ et al., 2015), while herbivore weight gain can be inversely related to herbivore survival (Veyrat et al., 2016). Host plant preference have been widely used to assess plant resistance against herbivores, through the analysis of feeding/oviposition reduction (antixenosis Stenberg and Muola, 2017). Unfortunately, this is a reliable analysis only for large herbivores, which can directly determine the formation of reproductive structures and plant survival (Huber et al., 2016; Machado et al., 2016; Erb, 2018). For small herbivores such as arthropods, antixenosis as a proximate variable for the study of plant defenses can have limitations, mostly related to the different preferences of adults and juveniles (Clark et al., 2011), difficult to mimic the field situation in lab conditions (Schuman et al., 2015) or the complexity of interaction between the plant and several other herbivores (Kessler and Baldwin, 2004). Leaf damage assessments are often used because they accurately mirror the severity of attack (Erb, 2018). Even though in some cases there is a clear relation between plant damage and yield penalty (Vichitbandha and Chandrapatya, 2011), the relationship between the two variables is not always linear, and many plants can sustain herbivore damage without suffering significant yield penalties through tolerance (Scholes and Paige, 2014; Lehndal and Ågren, 2015; Erb, 2018). We have seen such behaviour in our lab with a rice cultivar infested by Schizotetranychus oryzae, in which mite population and leaf damage increased consistently throughout the vegetative and reproductive stages, resulting in no grain yield reduction, while other cultivars showed reductions of more than 60\% (unpublished data). Furthermore, recording the exact extent of plant damage caused by most of the herbivores remains challenging and somewhat subjective, due to the need of a visual damage scale, unless quantified in standardized units of leaf area consumed relative to herbivore size (Fragoso et al., 2014) or using image softwares.

\section{IT'S TIME TO LOOK AT PLANT TOLERANCE}

Another point that favors the more widely exploitation of tolerance mechanisms in crop protection strategies is the fact that antibiosis and antixenosis typically deter herbivore feeding, likely imposing a strong selection pressure on the herbivore to overcome plant resistance (similar to what happen with pesticides). On the other hand, plant tolerance have no effect on herbivore biology or behavior, and therefore is unlikely to impose selection on the herbivore (Mitchell et al., 2016). Thus, plant tolerance is considered a more stable management strategy for pests (Weis and Franks, 2006; Peterson et al., 2017), with greater chance of providing long-lasting pest control (Mitchell et al., 2016). Therefore, based on all these points, we suggest the analysis of plant tolerance mechanisms and yield/productivity in every crop-mite interaction (which could probably be extended to most of the herbivorous pests). In fact, this is what really matters to crop farmers, and academic studies should be aligned with these needs.

It is important to highlight that we are not suggesting the replacement of crop resistance studies by crop tolerance ones. 
TABLE 1 | Studies on crop-mite interactions since 2009.

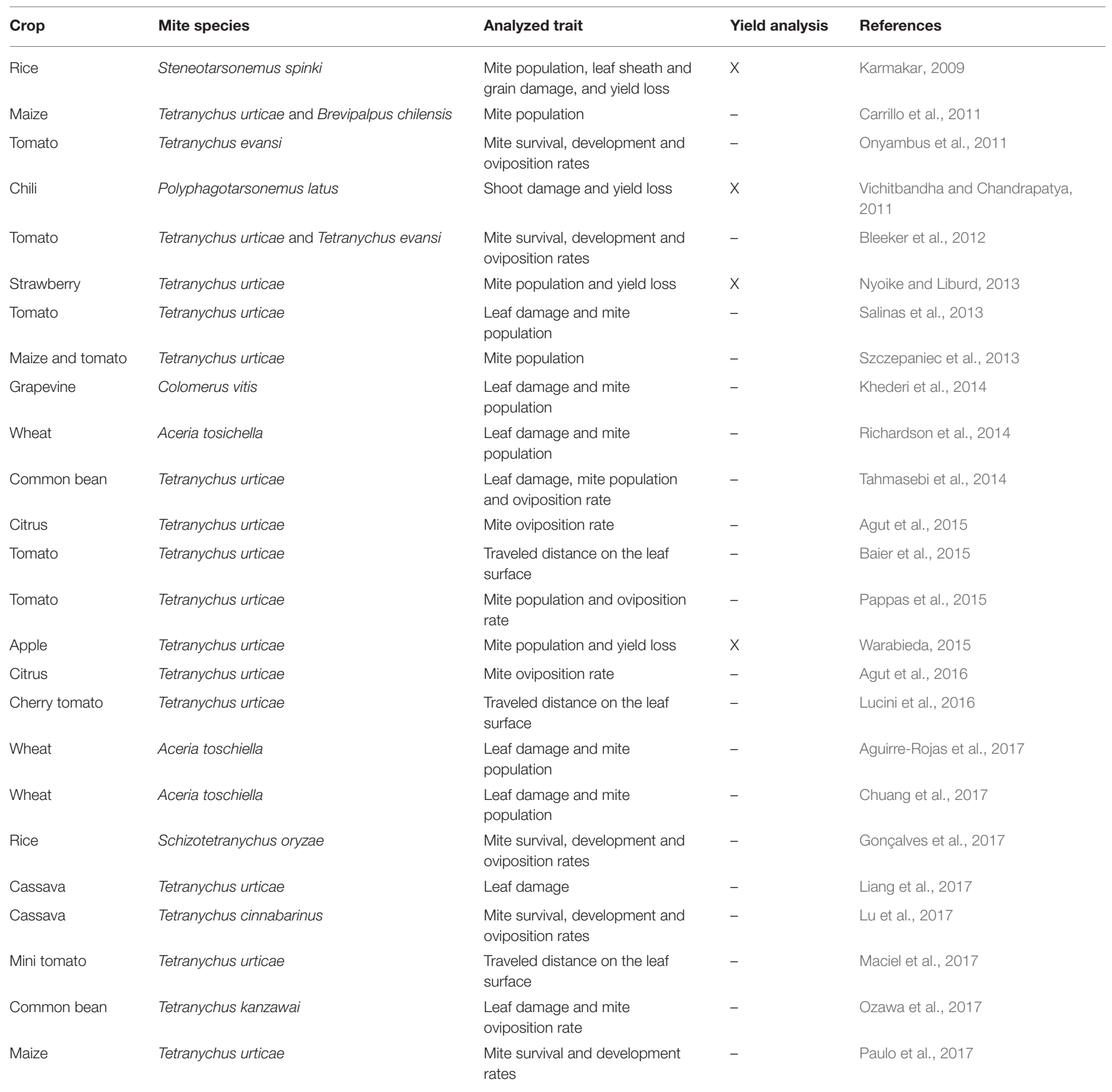

We believe that both defense strategies should be extensively analyzed. We agree with the statement of Peterson et al. (2017): "Before substantial work on tolerance development can occur, we must conduct basic research on the physiological and biochemical mechanisms of tolerance. This must involve interdisciplinary research between plant scientists and entomologists." On the other hand, in a couple of years we would like to say: no, plant tolerance is not "the forgotten child of plant resistance." We believe that basic understanding of how plants cope with herbivory and the identification of tolerant genotypes from important crops will have a major impact in pest control and grain yield.

\section{AUTHOR CONTRIBUTIONS}

All authors listed have made a substantial, direct and intellectual contribution to the work, and approved it for publication. 


\section{REFERENCES}

Aguirre-Rojas, L. M., Khalaf, L. K., Garcés-Carrera, S., Sinha, D. K., Chuang, W. P., and Smith, C. M. (2017). Resistance to wheat curl mite in arthropod-resistant rye-wheat translocation lines. Agronomy 7:74. doi: 10.3390/agronomy7040074

Agut, B., Gamir, J., Jaques, J. A., and Flors, V. (2015). Tetranychus urticaetriggered responses promote genotype-dependent conspecific repellence or attractiveness in citrus. New Phytol. 207, 790-804. doi: 10.1111/nph.13357

Agut, B., Gamir, J., Jaques, J. A., and Flors, V. (2016). Systemic resistance in citrus to Tetranychus urticae induced by conspecifics is transmitted by grafting and mediated by mobile amino acids. J. Exp. Bot. 67, 5711-5723. doi: 10.1093/jxb/erw335

Baier, J. E., Resende, J. T., Faria, M. V., Schwarz, K., and Meert, L. (2015). Indirect selection of industrial tomato genotypes that are resistant to spider mites (Tetranychus urticae). Genet. Mol. Res. 14, 244-252. doi: 10.4238/2015.January.16.8

Bleeker, P. M., Mirabella, R., Diergaarde, P. J., VanDoorn, A., Tissier, A., and Kant, M. R., et al. (2012). Improved herbivore resistance in cultivated tomato with the sesquiterpene biosynthetic pathway from a wild relative. Proc. Natl. Acad. Sci. U.S.A. 109, 20124-20129. doi: 10.1073/pnas.1208756109

Carrillo, L., Martinez, M., Ramessar, K., Cambra, I., Castañera, P., Ortego, F., et al. (2011). Expression of a barley cystatin gene in maize enhances resistance against phytophagous mites by altering their cysteine-proteases. Plant Cell Rep. 30, 101-112. doi: 10.1007/s00299-010-0948-z

Chuang, W. P., Rojas, L. M. A., Khalaf, L. K., Zhang, G., Fritz, A. K., Whitfield, A. E., et al. (2017). Wheat genotypes with combined resistance to wheat curl mite, wheat streak mosaic virus, wheat mosaic virus, and Triticum mosaic virus. J. Econ. Entomol. 110, 711-718. doi: 10.1093/jee/tow255

Clark, K. E., Hartley, S. E., and Johnson, S. N. (2011). Does mother know best? The preference-performance hypothesis and parent-offspring conflict in aboveground-belowground herbivore life cycles. Ecol. Entomol. 36, 117-124. doi: 10.1111/j.1365-2311.2010.01248.x

Clavijo McCormick, A., Unsicker, S. B., and Gershenzon, J. (2012). The specificity of herbivore-induced plant volatiles in attracting herbivore enemies. Trends Plant Sci. 17, 303-310. doi: 10.1016/j.tplants.2012.03.012

Erb, M. (2018). Plant defenses against herbivory: closing the fitness gap. Trends Plant Sci. 23, 187-194. doi: 10.1016/j.tplants.2017.11.005

Fragoso, V., Rothe, E., Baldwin, I. T., and Kim, S. G. (2014). Root jasmonic acid synthesis and perception regulate folivore-induced shoot metabolites and increase Nicotiana attenuata resistance. New Phytol. 202, 1335-1345. doi: $10.1111 / \mathrm{nph} .12747$

Gonçalves, D., da Cunha, U. S., Radaelli, T. F. S., and Ferla, N. J. (2017). Influence of different rice cultivars on Schizotetranychus oryzae development. Neotrop. Entomol. 46, 336-340. doi: 10.1007/s13744-016-0458-y

Huber, M., Bont, Z., Fricke, J., Brillatz, T., Aziz, Z., Gershenzon, J., et al. (2016). A below-ground herbivore shapes root defensive chemistry in natural plant populations. Proc. Biol. Sci. 283:20160285. doi: 10.1098/rspb. 2016.0285

Karmakar, K. (2009). Steneotarsonemus spinki Smiley (Acari: Tarsonemidae) - a yield reducing mite of rice crops in West Bengal, India. Int. J. Acarol. 34, 95-99. doi: $10.1080 / 01647950808683710$

Kessler, A., and Baldwin, I. T. (2004). Herbivore-induced plant vaccination. Part, I. The orchestration of plant defenses in nature and their fitness consequences in the wild tobacco Nicotiana attenuata. Plant, J. 38, 639-649. doi: 10.1111/j.1365-313X.2004.02076.x

Khederi, S. J., de Lillo, E., Khanjani, M., and Gholami, M. (2014). Resistance of grapevine to the erineum strain of Colomerus vitis (Acari: Eriophyidae) in western Iran and its correlation with plant features. Exp. Appl. Acarol. 63, 15-35. doi: 10.1007/s10493-0149778-y

Lehndal, L., and Ågren J (2015). Herbivory differentially affects plant fitness in three populations of the perennial herb Lythrum salicaria along a latitudinal gradient. PLOS ONE 10:e0135939. doi: 10.1371/journal.pone. 0135939

Liang, X., Chen, Q., Lu, H., Wu, C., Lu, F., and Tang, J. (2017). Increased activities of peroxidase and polyphenol oxidase enhance cassava resistance to Tetranychus urticae. Exp. Appl. Acarol. 71, 195-209. doi: 10.1007/s10493-017-0125-y
Lu, F., Liang, X., Lu, H., Li, Q., Chen, Q., Zhang, P., et al. (2017). Overproduction of superoxide dismutase and catalase confers cassava resistance to Tetranychus cinnabarinus. Sci. Rep. 7:40179. doi: 10.1038/srep40179

Lu, J., Robert, C. A., Riemann, M., Cosme, M., Mène-Saffran,é, L., Massana, J., et al. (2015). Induced jasmonate signaling leads to contrasting effects on root damage and herbivore performance. Plant Physiol. 167, 1100-1116. doi: 10.1104/pp.114.252700

Lucini, T., Resende, J. T., Oliveira, J. R., Scabeni, C. J., Zeist, A. R., and Resende, N. C. (2016). Repellent effects of various cherry tomato accessions on the two-spotted spider mite Tetranychus urticae Koch (Acari: Tetranychidae). Genet. Mol. Res. 15:15017736. doi: 10.4238/gmr.150 17736

Machado, R. A., McClure, M., Hervé, M. R., Baldwin, I. T., and Erb, M. (2016). Benefits of jasmonate-dependent defenses against vertebrate herbivores in nature. Elife 5:e13720. doi: 10.7554/eLife.13720

Maciel, G. M., Almeida, R. S., da Rocha, J. P., Andaló, V., Marquez, G. R., Santos, N. C., et al. (2017). Mini tomato genotypes resistant to the silverleaf whitefly and to two-spotted spider mites. Genet. Mol. Res. 16:gmr16019539. doi: 10.4238/gmr16019539

Mitchell, C., Brennan, R. M., Graham, J., and Karley, A. J. (2016). Plant defense against herbivorous pests: exploiting resistance and tolerance traits for sustainable crop protection. Front. Plant Sci. 7:1132. doi: $10.3389 /$ fpls.2016.01132

Nyoike, T. W., and Liburd, O. E. (2013). Effect of Tetranychus urticae (Acari: Tetranychidae), on marketable yields of field-grown strawberries in northcentral Florida. J. Econ. Entomol. 106, 1757-1766. doi: 10.1603/EC12033

Onyambus, G. K., Maranga, R. O., Gitonga, L. M., and Knapp, M. (2011). Host plant resistance among tomato accessions to the spider mite Tetranychus evansi in Kenya. Exp. Appl. Acarol. 54, 385-393. doi: 10.1007/s10493-011-9446-4

Ozawa, R., Endo, H., Iijima, M., Sugimoto, K., Takabayashi, J., Gotoh, T., et al. (2017). Intraspecific variation among Tetranychid mites for ability to detoxify and to induce plant defenses. Sci. Rep. 7:43200. doi: 10.1038/srep 43200

Pappas, M. L., Steppuhn, A., Geuss, D., Topalidou, N., Zografou, A., Sabelis, M. W., et al. (2015). Beyond predation: the zoophytophagous predator Macrolophus pygmaeus induces tomato resistance against spider mites. PLoS ONE 10:e0127251. doi: 10.1371/journal.pone.0127251

Paulo, P. D., Lima, C. G., Dominiquini, A. B., Fadini, M. A. M., Mendes, S. M., and Marinho, C. G. S. (2017). Maize plants produce direct resistance elicited by Tetranychus urticae Koch (Acari: Tetranychidae). Braz. J. Biol. 78, 13-17. doi: 10.1590/1519-6984.19915

Peterson, R. K. D., Varella, A. C., and Higley, L. G. (2017). Tolerance: the forgotten child of plant resistance. PeerJ 5:e3934. doi: 10.7717/peerj.3934

Poelman, E. H. (2015). From induced resistance to defence in plant-insect interactions. Entomol. Exp. Appl. 157, 11-17. doi: 10.1111/eea.12334

Richardson, K., Miller, A. D., Hoffmann, A. A., and Larkin, P. (2014). Potential new sources of wheat curl mite resistance in wheat to prevent the spread of yield-reducing pathogens. Exp. Appl. Acarol. 64, 1-19. doi: 10.1007/s10493-014-9808-9

Rioja, C., Zhurov, V., Bruinsma, K., Grbic, M., and Grbic, V. (2017). Plantherbivore interactions: a case of an extreme generalist, the two-spotted spider mite Tetranychus urticae. Mol. Plant Microbe Interact. 30, 935-945. doi: 10.1094/MPMI-07-17-0168-CR

Salinas, M., Capel, C., Alba, J. M., Mora, B., Cuartero, J., FernándezMuñoz, R., et al. (2013). Genetic mapping of two QTL from the wild tomato Solanum pimpinellifolium L. controlling resistance against two-spotted spider mite (Tetranychus urticae Koch). Theor. Appl. Genet. 126, 83-92. doi: 10.1007/s00122-012-1961-0

Scholes, D. R., and Paige, K. N. (2014). Plasticity in ploidy underlies plant fitness compensation to herbivore damage. Mol. Ecol. 23, 4862-4870. doi: $10.1111 /$ mec. 12894

Schuman, M. C., Allmann, S., and Baldwin, I. T. (2015). Plant defense phenotypes determine the consequences of volatile emission for individuals and neighbors. Elife 4:e04490. doi: 10.7554/eLife.04490

Stenberg, J. A., and Muola, A. (2017). How should plant resistance to herbivores be measured? Front. Plant Sci. 8:663. doi: 10.3389/fpls.2017.00663

Szczepaniec, A., Raupp, M. J., Parker, R. D., Kerns, D., and Eubanks, M. D. (2013). Neonicotinoid insecticides alter induced defenses and increase 
susceptibility to spider mites in distantly related crop plants. PLoS ONE 8:e62620. doi: 10.1371/journal.pone.0062620

Tahmasebi, Z., Mohammadi, H., Arimura, G., Muroi, A., and Kant, M. R. (2014). Herbivore-induced indirect defense across bean cultivars is independent of their degree of direct resistance. Exp. Appl. Acarol. 63, 217-239. doi: 10.1007/s10493-014-9770-6

Veyrat, N., Robert, C. A. M., Turlings, T. C. J., and Erb, M. (2016). Herbivore intoxication as a potential primary function of an inducible volatile plant signal. J. Ecol. 104, 591-600. doi: 10.1111/1365-2745. 12526

Vichitbandha, P., and Chandrapatya, A. (2011). Broad mite effects on chili shoot damage and yields. Pak. J. Zool. 43, 637-649.

Warabieda, W. (2015). Effect of two-spotted spider mite population (Tetranychus urticae Koch) on growth parameters and yield of the summer apple cv. Katja. Hort. Sci. 42, 167-175. doi: 10.17221/259/2014-HORTSCI
Weis, A. E., and Franks, S. J. (2006). Herbivory tolerance and coevolution: an alternative to the arms race? New Phytol. 170, 423-425. doi: 10.1111/j.1469-8137.2006.01745.x

Conflict of Interest Statement: The authors declare that the research was conducted in the absence of any commercial or financial relationships that could be construed as a potential conflict of interest.

Copyright (๑) 2018 Sperotto, Buffon, Schwambach and Ricachenevsky. This is an open-access article distributed under the terms of the Creative Commons Attribution License (CC BY). The use, distribution or reproduction in other forums is permitted, provided the original author(s) and the copyright owner are credited and that the original publication in this journal is cited, in accordance with accepted academic practice. No use, distribution or reproduction is permitted which does not comply with these terms. 